\title{
Library of Congress to Host Open House at Annual Meeting
}

APSA members attending the Annual Meeting in Washington will have a special opportunity to learn about the vast holdings at the Library of Congress by attending a special open house or one of two research orientation sessions. The Library's collections are the most extensive in the world, including the laws and government regulations of other countries, foreign language materials, and American publications on all subjects. Its expert staff can guide and assist with bibliographic and subject-matter searches in approximately 150 languages and all formats. In addition to books, serials, and newspapers, the Library has extensive manuscript, map, photograph, film, recorded sound, and music collections.

\section{Open House}

On Thursday, August 31 and Friday, September 1, 12 of the Library's main reading rooms will be open to all individuals registered for the Annual Meeting. Library staff will be on hand at each site to describe the collections and answer questions. No registration is required. Additionally, tours of the Jefferson Building will be offered on Thursday and Friday.

\section{Research Orientation Session}

Those wishing to receive a more detailed overview are invited to attend a research orientation session on Friday, September 1, from either $9: 30$ to $11: 30$ a.m. or $1: 30$ to $3: 30$ p.m. Registrants will receive a description of the Library's collections and electronic and print resources and an introduction to subject searching in a closed-stack library. They will also get suggestions for conducting research efficiently in the Library and instruction on how to effectively use Library of Congress subject headings. At the end of the session, participants will walk through the Scholars' Colonnade and obtain reader registration cards. The sessions will be taught by Paul Baker, a political science specialist in the Library's Humanities and Social Sciences Division.

Each session is open to a maximum of 25 individuals. To reserve a spot, contact Mr. Baker by noon on August 30 at 202-707-0939 or pbak@loc.gov.

\section{Fellowships at LOC}

Beginning in the 2001-02 academic year, up to 10 postdoctoral fellowships for research in the Library's foreign language collections, supported by the Mellon and Luce Foundations, will be available by application through the American Council of Learned Societies. The deadline for applications is October 2,2000 .

Information about this and other fellowships for postdoctoral research, especially those supporting use of the foreign language collections, may be obtained from the Office of Scholarly Programs, Library of Congress LJ 120, 101 Independence Ave., SE, Washington, DC 20540-4860; 202-707-3302; pgif@loc.gov.

\section{Jewel L. Prestage Award Call for Nominations}

The Southwestern Political Science Association invites nominations for the Jewel L. Prestage Award for the Best Paper on Gender, Race, Ethnicity and Political Behavior presented at the 2001 SWPSA annual meeting March 15-18, 2001, in Fort Worth, Texas. The paper award was established in honor of Professor Jewel L. Prestage, whose intellectual contributions to the study of gender, race, and political behavior, devotion to the professional success of her students, and service to the discipline (including service as vice president and acting president [1967-68] and program chair [1967-68] of the SWPSA and president of the Southwestern Social Science Association [1974-75]) have enriched the SWPSA and the discipline, both professionally and personally.

The Prestage Award recognizes excellence in research on the intersection of gender, race, ethnicity, and political behavior. To be eligible for the award, papers must be submitted for presentation at the 2001 annual meeting of the SWPSA; the deadline for paper proposals for that meeting is October 6, 2000. Papers submitted for consideration of the Prestage Award may be self-nominated and should be submitted no later than February 15, 2001, to Jan Leighley, Department of Political Science, Texas A\&M University, 4348 TAMU, College Station, Texas 77843-4348. The award carries a cash prize, and the winner will be recognized at the annual business meeting of the SWPSA in Fort Worth as part of the 2001 annual meeting. For further information, contact Jan Leighley via email at leighley@polisci.tamu.edu or phone at 979-845-2525. 